\title{
Performa Ayam Merawang dalam Berbagai Umur dengan Tingkat Pemberian Bungkil Inti Sawit dalam Ransum
}

\section{Performance of Merawang Chicken in Various Ages with the Level of Palm Kernel Cake in the Ration}

\author{
Nuraini*, Z. Hidayat, dan S. Puspito \\ Balai Pengkajian Teknologi Pertanian Kepulauan Bangka Belitung, Jl. Mentok Km. 4 Pangkalpinang \\ 33134 - Indonesia \\ *Corresponding E-mail: noenoenk_sky@yahoo.co.id
}

(Diterima: 23 September 2019; Disetujui: 25 November 2019)

\begin{abstract}
ABSTRAK
Tujuan dari penelitian ini adalah untuk mengetahui performa ayam Merawang umur 4, 6, dan 8 bulan yang menggunakan bungkil inti sawit (BIS) di dalam ransum. Rancangan yang digunakan adalah rancangan acak lengkap (RAL) faktorial dengan 4 level pemberian bungkil sawit sebagai faktor pertama dan 3 level umur ayam sebagai faktor ke dua dan setiap unit percobaan terdiri dari 6 ekor. Ransum perlakuan terdiri atas perlakuan 100\% ransum komersial, 90\% ransum komersial $+10 \%$ BIS, 80\% ransum komersial $+20 \%$ BIS dan $70 \%$ ransum komersial $+30 \%$ BIS. Variabel yang diamati meliputi pertambahan berat badan, konsumsi pakan, dan konversi pakan. Hasil penelitian menunjukkan bahwa pemberian bungkil inti sawit dalam ransum ayam Merawang sampai dengan level 30\% tidak memberikan pengaruh yang nyata terhadap performa ayam Merawang namun perbedaan umur ayam memberikan pengaruh yang nyata terhadap performa ayam Merawang. Kesimpulan bungkil sawit dapat diberikan dalam campuran pakan ayam Merawang sampai dengan tingkat $30 \%$.
\end{abstract}

Kata kunci: ayam Merawang, bungkil inti sawit, performa

\section{ABSTRACT}

Performance of Merawang Chicken in various ages with the level of palm kernel cake in the ration. The objective of the study is to determine the effect of using palm kernel cake (PKC) in rations on the performance of Merawang chickens aged 4, 6 and 8 months. Experimental Design used was a factorial completely randomized $4 \times 3$, the first factor was levels of palm kernel cake (PKC) and the second factor was the difference in age of chicken and each experimental unit consisted of 6 individuals. The treatments consisted of treatment 100\% commercial feed, 90\% commercial feed $+10 \%$ PKC, 80\% commercial feed $+20 \%$ PKC and 70\% commercial feed $+30 \%$ PKC. The variables observed were weight gain, feed consumption, and feed conversion. The results showed that the use of palm kernel cake in the Merawang chicken feeds up to $30 \%$, it does not have a significant effect on the performance of Merawang chicken but the difference in age of chicken was have a significant effect for the performance of Merawang chicken. it showed that palm kernel cake can be used in Merawang chicken feed up to $30 \%$.

Keywords: Merawang chicken, palm kernel cake, performance

\section{PENDAHULUAN}

Peternakan unggas mempunyai potensi yang besar untuk dikembangkan di Kepulauan Bangka Belitung mengingat konsumsi daging ayam di Bangka Belitung sendiri mencapai 12.877 ton/tahun (BPS
Babel, 2018) dan sebagian besar masih di datangkan dari luar Bangka Belitung. Salah satu potensi unggas yang bisa dikembangkan adalah ayam Merawang yang merupakan ayam buras lokal asli Bangka Belitung dengan potensi menjadi ayam pedaging sekaligus petelur. Budidaya ayam Merawang di Bangka 
Belitung masih dilakukan secara tradisional dan seperti pada peternakan unggas lainnya pakan masih menjadi masalah terbesar dalam meningkatkan efisiensi produksi. Pada semua usaha peternakan, pakan menjadi hal yang sangat penting karena merupakan komponen utama yang mempengaruhi produktivitas suatu hewan ternak. Menurut Dewanti et al. (2012) biaya pakan mencapai $76,16 \%$ dari biaya produksi suatu usaha peternakan. Harga pakan ayam di Kepulauan Bangka Belitung relatif mahal, Rp 9.000 - Rp 10.000 $/ \mathrm{kg}$, disebabkan karena bahan baku penyusun ransum masih impor (Resnawati et al., 2000). Penghematan biaya pakan tentu akan memberikan keuntungan bagi peternak. Oleh karena itu untuk mengurangi biaya produksi dengan tetap memperhatikan produktifitas yang tinggi perlu dilakukan upaya yang tepat salah satunya dengan memanfaatkan bahan pakan alternatif yang mempunyai kandungan nutrisi yang baik, mudah didapat, murah, dan tidak bersaing dengan kebutuhan manusia serta efektif dan efisien dalam penggunaannya salah satunya adalah dengan memanfaatkan limbah industri perkebunan.

Di Indonesia industri perkebunan yang berkembang sangat besar adalah industri kelapa sawit dengan kapasitas produksi pada tahun 2017 mencapai 6,8 Juta ton dengan luas lahan sebesar 12,2 juta ha (BPS, 2018) dan menghasilkan limbah yang cukup besar. Produksi limbah industri kelapa sawit menurut Ditjenbun (2017) adalah 20 juta ton mesocorp fibre, 9 juta ton cangkang, 31 juta ton tandan kosong, dan bungkil inti sawit mencapai 3,1 juta ton. Bungkil inti sawit merupakan bahan yang berpotensi sebagai pakan unggas dengan kandungan nutrisi kadar protein antara 14,1921,66\%, lemak 9,5-10,5\% dan serat kasar 12-63\% (Pasaribu, 2018) sehingga layak dilakukan pengkajian mengenai pemanfaatan bungkil sawit sebagai salah satu alternatif pakan unggas.

Pada tahun 2017 produksi kelapa sawit di Bangka Belitung mencapai 586.883 ton (Ditjenbun, 2017) dan limbah khususnya bungkil inti sawit sangat berpotensi sebagai bahan pakan unggas lokal unggul yang telah terdaftar sebagai kekayaan lokal Bangka Belitung yaitu ayam Merawang. Menurut Nataamijaya (2010), Ayam merawang salah satu ayam lokal yang berasal dari spesies Gallus-gallus, family Phasianidae yang berpotensi dikembangkan menjadi ayam pedaging dan sekaligus ayam petelur dengan produksi telur mencapai 125 butir/ tahun (Nuraini et al., 2016) sedangkan ayam Merawang jantan dan betina memiliki pesentase karkas masing-masing sebesar 62,78 dan 55,28\% (Nuraini et al., 2018).

Penelitian untuk mengetahui pengaruh pemanfaatan bungkil inti sawit dalam ransum terhadap performa ayam Merawang perlu dilakukan sehingga diharapkan dapat memadukan potensi lokal yang ada serta kedepannya dapat meningkatkan kesejahteraan masyarakat.

Tujuan penelitian ini adalah mengetahui pengaruh penggunaan bungkil inti sawit (BIS) dalam ransum terhadap performa ayam Merawang umur 4, 6, dan 8 bulan. Dengan mengetahui pengaruh tersebut maka potensi lokal ayam Merawang bisa lebih ditingkatkan dengan memanfaatkan limbah industri kelapa sawit lokal.

\section{METODE}

Penelitian ini dilaksanakan di KP Petaling BPTP Kepulauan Bangka Belitung dimulai dari bulan Agustus-Oktober 2018. Penelitian ini menggunakan materi berupa ayam Merawang sebanyak 72 ekor yang terdiri dari 12 ekor jantan dan 60 ekor betina dengan 3 perbedaan umur yang terbagi kedalam 12 kelompok perlakuan yaitu 4 level pemberian bungkil sawit $(0 \%, 10 \%, 20 \%$, dan $30 \%)$ dan 3 level kategori umur ayam (4, 6, dan 8 bulan). Pemeliharaan ayam dilakukan secara semi intensif dengan menggunakan sistem kandang ren dimana ternak dilepas pada siang hari di halaman exercise berpagar. Rasio perbandingan antara ayam Merawang jantan dan betina adalah 1:5. 
Tabel 1. Komposisi pakan dengan tingkat bungkil inti sawit sampai $30 \%$

\begin{tabular}{lcccc}
\hline \multirow{2}{*}{ Bahan Pakan } & \multicolumn{4}{c}{ Perlakuan } \\
\cline { 2 - 5 } & P0 & P1 & P2 & P3 \\
\hline Dedak (\%) & 35 & 35 & 35 & 35 \\
Jagung (\%) & 30 & 30 & 30 & 30 \\
Konsentrat (\%) & 35 & 25 & 15 & 5 \\
Bungkil Inti Sawit (\%) & 0 & 10 & 20 & 30 \\
\hline Total & 100 & 100 & 100 & 100 \\
\hline
\end{tabular}

Tabel 2. Kandungan nutrien masing-masing perlakuan

\begin{tabular}{lcccc}
\hline \multirow{2}{*}{ Kandungan Nutrien* } & \multicolumn{4}{c}{ Perlakuan } \\
\cline { 2 - 5 } & P0 & P1 & P2 & P3 \\
\hline Air (\%) & 12,15 & 11,87 & 11,15 & 11,10 \\
Protein (\%) & 12,69 & 12,11 & 11,49 & 10,41 \\
Energi (Kcal/kg) & 3.939 & 3.887 & 3.948 & 3.938 \\
Abu (\%) & 6,61 & 7,69 & 6,94 & 6,63 \\
Ca (\%) & 0,22 & 0,39 & 0,14 & 0,12 \\
P (\%) & 0,36 & 0,37 & 0,39 & 0,34 \\
\hline
\end{tabular}

Keterangan: *Hasil analisis proksimat laboratorium Balitnak Ciawi

Ransum untuk penelitian ini terdiri dari campuran antara konsentrat, jagung, dedak, dan bungkil sawit. Komposisi pakan dan kandungan nutrien masing-masing pakan perlakuan disajikan dalam Tabel 1 dan 2 . Bahan-bahan pakan komersil yang digunakan dibeli dari Poultry Shop. Pakan diberikan sehari 2 kali pada pagi dan sore sedangkan air minum diberikan secara ad libitum.

Penelitian ini menggunakan Rancangan Acak Lengkap (RAL) Faktorial 4 x 3 sebagai rancangan percobaannya dengan faktor pertama adalah level bungkil sawit dan faktor kedua adalah umur ayam. Peubah yang diamati yaitu: konsumsi ransum, konversi ransum serta pertambahan bobot badan dengandengan perhitungan rumus sebagai berikut (Anggraini et al., 2019):

Konsumsi Pakan $(\mathrm{g})=$

Pemberian pakan $(\mathrm{g})$ - Sisa pakan $(\mathrm{g})$

Konversi Pakan $=\underline{\text { Konsumsi pakan }(\mathrm{g})}$ Pertambahan bobot badan (g)
Pertambahan bobot badan $(\mathrm{g})=$

Rataan berat awal (g) - Rataan berat akhir (g) Lama pemeliharaan (hari)

Data yang di dapat dari penelitian ini akan dianalisa menggunakan ANOVA dan dilakukan uji lanjut menggunakan Duncan Multiple Range Test (DMRT) jika hasil analisis menunjukkan berbeda nyata (Gomez and Gomez, 1984).

\section{HASIL DAN PEMBAHASAN}

\section{Pertambahan Bobot Badan Harian (PBBH)}

Pertambahan bobot badan harian digunakan untuk mengukur pertumbuhan. Hasil analisa statistik menunjukkan bahwa pemberian bungkil sawit selama perlakuan sampai level $30 \%$ tidak menunjukkan pengaruh yang berbeda nyata $(\mathrm{P} \leq 0,05)$ tetapi perbedaan umur memberikan pengaruh yang berbeda nyata $(\mathrm{P} \leq 0,05)$ terhadap pertambahan bobot badan harian ayam Merawang (Tabel 3). Rataan pertambahan bobot badan harian ayam Merawang dengan nilai tertinggi pada level perlakuan pemberian bungkil sawit 
Tabel 3. Rataan PBBH (g) ayam Merawang selama penelitian

\begin{tabular}{lcccc}
\hline \multirow{2}{*}{ Perlakuan } & \multicolumn{3}{c}{ Umur } & \multirow{2}{*}{ Rataan } \\
\cline { 2 - 4 } & 8 Bulan & 6 Bulan & 4 Bulan & \\
\hline P0 & $2,13^{\mathrm{aA}}$ & $6,42^{\mathrm{bA}}$ & $12,48^{\mathrm{cA}}$ & $7,01^{\mathrm{A}}$ \\
P1 & $5,11^{\mathrm{aA}}$ & $7,95^{\mathrm{bA}}$ & $9,84^{\mathrm{cB}}$ & $7,63^{\mathrm{A}}$ \\
P2 & $3,88^{\mathrm{aA}}$ & $8,64^{\mathrm{bA}}$ & $12,52^{\mathrm{cA}}$ & $8,34^{\mathrm{A}}$ \\
P3 & $2,97^{\mathrm{aA}}$ & $5,47^{\mathrm{bA}}$ & $12,07^{\mathrm{cA}}$ & $6,84^{\mathrm{A}}$ \\
\hline Rataan & $3,52^{\mathrm{a}}$ & $7,12^{\mathrm{b}}$ & $11,73^{\mathrm{c}}$ & \\
\hline
\end{tabular}

Keterangan: Berbeda nyata pada taraf $5 \%$ (huruf kecil yang berbeda ke arah kolom/lajur); Tidak berbeda nyata pada taraf $5 \%$ (huruf besar yang sama ke arah baris)

sebanyak $20 \%$ dan terendah pada $30 \%$ walaupun secara keseluruhan pemberian bungkil sawit pada pakan sampai dengan level $30 \%$ tidak berpengaruh yang nyata terhadap pertambahan bobot badan harian ayam Merawang. Pertambahaan bobot badan harian yang tidak berbeda ini disebabkan kualitas nutrisi dan kandungan nutrisi pakan pada masing-masing perlakuaan yang tidak jauh berbeda (Tabel 2). Hasil tersebut sesuai dengan pendapat Wahyu (2015), bahwa kualitas pakan sangat berpengaruh terhadap pertumbuhan ternak, sedangkan Iskandar (2010) menyatakan bahwa jenis ayam, jenis kelamin, bobot hidup, ransum, dan umur juga mempengaruhi bobot badan.

Berdasarkan hasil analisis dapat dilihat bahwa pertambahan bobot badan harian ayam Merawang pada masing-masing umur menunjukkan hasil yang berbeda nyata. Pertambahan bobot badan tertinggi didapatkan pada ayam Merawang umur 4 bulan kemudian diikuti umur 6 bulan dan pertambahan bobot badan terendah didapat pada umur 8 bulan. Pertambahan bobot badan tertinggi pada ayam umur 4 bulan disebabkan karena fase pertumbuhan optimal ayam terjadi pada umur maksimal 12 minggu. Hal ini sesuai pendapat Iskandar et al. (1998) bahwa pertumbuhan ayam maksimal terjadi pada umur 1-12 minggu. Hormon pertumbuhan atau growth hormone merupakan salah satu hormon yang berpengaruh terhadap proses pertumbuhan sehingga dapat mempengaruhi bobot badan (Bidura dan Suasta, 2006).

Performa Ayam Merawang dalam ... (Nuraini et al.)

\section{Konsumsi Pakan}

Konsumsi ransum adalah hasil pengurangan jumlah pakan yang diberikan dengan jumlah pakan yang tersisa (Sulandari et a1., 2007). Konsumsi ransum tertinggi didapat pada level perlakuan pemberian bungkil sawit sebanyak $20 \%$ dan terendah pada $0 \%$ (kontrol) (Tabel 4). Walaupun terlihat adanya perbedaan konsumsi pakan pada setiap level pemberian bungkil sawit, namun secara statistik tidak memberikan pengaruh yang berbeda nyata $(\mathrm{P} \leq 0,05)$. Sehingga dapat di katakan bahwa penggunaan bungkil sawit pada pakan ayam Merawang dapat diterima dengan baik sampai dengan level 30\% yang menggambarkan bahwa tingkat palatabilitas ayam terhadap bungkil sawit dalam pakan baik. Akan tetapi dapat dilihat bahwa konsumsi pakan ayam Merawang pada masing-masing umur ayam menunjukkan perbedaan yang nyata. Konsumsi pakan tertinggi didapatkan pada ayam Merawang umur 8 bulan kemudian diikuti umur 6 bulan dan terendah pada umur 4 bulan. Hal tersebut dapat dipastikan bahwa umur sangat mempengaruhi konsumsi pakan, dimana semakin tinggi umur ayam maka akan diikuti peningkatan konsumsi pakan karena tingkat kebutuhan dan metabolisme juga kan berbeda seiring bertambahnya umur ternak. Hal tersebut sesuai dengan pendapat Astuti (2012) bahwa konsumsi pakan dipengaruhi beberapa faktor yaitu kualitas pakan, palatabilitas, ukuran tubuh dan umur.

Konsumi pakan pada hasil penelitian ini berkorelasi negatif dengan pertambahan bobot badan yang didapatkan. Konsumsi 
JPI Vol. 22 (1): 66-72

Tabel 4. Konsumsi pakan (g) ayam Merawang selama penelitian

\begin{tabular}{lcccc}
\hline \multirow{2}{*}{ Perlakuan } & \multicolumn{3}{c}{ Umur } & \multirow{2}{*}{ Rataan } \\
\cline { 2 - 3 } P0 & 8 bulan & 6 bulan & 4 bulan & \\
P1 & $5.539,58^{\mathrm{aA}}$ & $4.351,66^{\mathrm{bA}}$ & $2.452,83^{\mathrm{cA}}$ & $4.115,00^{\mathrm{A}}$ \\
P2 & $6.125,16^{\mathrm{aA}}$ & $3.716,80^{\mathrm{bB}}$ & $2.710,00^{\mathrm{cA}}$ & $4.184,00^{\mathrm{A}}$ \\
P3 & $5.955,33^{\mathrm{aA}}$ & $4.870,50^{\mathrm{bA}}$ & $3.406,30^{\mathrm{cB}}$ & $4.744,00^{\mathrm{A}}$ \\
\hline Rataan & $6.228,50^{\mathrm{aA}}$ & $4.187,50^{\mathrm{bB}}$ & $2.346,00^{\mathrm{cA}}$ & $4.254,00^{\mathrm{A}}$ \\
\hline
\end{tabular}

Keterangan: Berbeda nyata pada taraf $5 \%$ (huruf kecil yang berbeda ke arah kolom/lajur); Tidak berbeda nyata pada taraf $5 \%$ (huruf besar yang sama ke arah baris)

pakan tertinggi tidak diikuti dengan pertambahan bobot badan yang tinggi juga. Hal ini dikarenakan perbedaan konsumi pakan menyesuaikan dengan umur dan aktivitas ternak. Ayam pada umur 6 dan 8 bulan, pakan yang dikonsumsi akan berkonsentrasi untuk mengubah pakan menjadi telur. Sesuai pendapat Hasnelly et al. (2006) bahwa ayam Merawang betina bertelur pertama kali pada umur 5,5 bulan.

\section{Konversi Pakan}

Efisiensi produksi merupakan hal yang penting dalam usaha peternakan dan untuk mengukurnya menggunakan rasio konversi pakan yang dipengaruhi oleh pertambahan bobot badan dan tingkat konsumsi pakan

Berdasarkan hasil penelitian (Tabel 5) dapat dilihat bahwa nilai rataan konversi pakan ayam Merawang tertinggi selama penelitian didapat pada level perlakuan pemberian bungkil sawit sebanyak $20 \%$ dan terendah pada $0 \%$ (kontrol). Konversi pakan pada perlakuan pemberian bungkil sawit pada level $0 \%$ tidak berbeda nyata dibandingkan dengan pemberian $10 \%$ tetapi berbeda nyata pada pemberian $20 \%$ dan $30 \%$. Akan tetapi konversi pakan ayam Merawang pada masingmasing umur ayam menunjukkan perbedaan nyata pada umur 3-4 bulan tetapi tidak berbeda pada umur 6 dan 8 bulan. Nilai konversi pakan yang paling baik pada hasil penelitian didapatkan pada ayam Merawang umur 3-4 bulan yaitu sebesar 1,82 . Yang artinya bahwa ayam pada umur ini dapat memanfaatkan pakan lebih baik untuk pertumbuhan bobot badan dibandingkan pada umur lainnya sehingga ayam bisa lebih dikembangkan untuk ayam pedaging. Konversi pakan merupakan perbandingan berapa jumlah pakan yang dapat di konversikan menjadi pertambahan berat badan sehingga nilai konversi pakan yang semakin kecil maka akan semakin baik. Menurut Zainal (2012) konversi pakan di artikan sebagai perbandingan antara konsumsi pakan yang diberikan dengan pertumbuhan bobot badan dan berhubungan erat dengan efisiensi pakan selama pertumbuhan.

Rataan konversi pakan hasil penelitian dengan pemberian bungkil sawit sampai dengan level 30\% lebih rendah jika dibandingkan dengan hasil penelitian yang dilakukan oleh Majid (2020) yang menggunakan bungkil inti sawit (BIS) dalam ransum ayam Merawang dan ayam Kampung sebesar 6,19 dan 6,14 pada umur 5-12 minggu. Hasil ini juga lebih rendah dibanding konversi pakan persilangan ayam Kampung dengan ayam Kampung sebesar 3,31 dan persilangan ayam Pelung dengan ayam Kampung sebesar 3,46 dengan pemeliharaan intensif (Iskandar et al., 2000). Serta lebih rendah dibanding ayam KUB sebesar 3,15-3,70 (Suryana et al., 2014). Beberapa faktor yang berpengaruh terhadap konversi pakan antara lain kualitas pakan, kualitas DOC, kualitas kandang, dan manajemen pemeliharaan (Fontana et al., 1992; Andriyanto et al., 2015).

\section{KESIMPULAN}

Dari hasil penelitian diatas dapat disimpulkan bahwa pemberian bungkil 
Tabel 5. Konversi pakan ayam Merawang selama penelitian

\begin{tabular}{lcccc}
\hline \multirow{2}{*}{ Perlakuan } & \multicolumn{3}{c}{ Umur } & \multirow{2}{*}{ Rataan } \\
\cline { 2 - 4 } & 8 bulan & 6 bulan & 4 bulan & \\
\hline P0 & 2,80 & 2,40 & 1,30 & $2,18^{\mathrm{A}}$ \\
P1 & 2,80 & 2,30 & 1,80 & $2,32^{\mathrm{AB}}$ \\
P2 & 3,30 & 3,04 & 2,50 & $2,92^{\mathrm{C}}$ \\
P3 & 3,30 & 3,30 & 1,70 & $2,78^{\mathrm{BC}}$ \\
\hline Rataan & $3,05^{\mathrm{a}}$ & $2,76^{\mathrm{a}}$ & $1,83^{\mathrm{b}}$ & \\
\hline
\end{tabular}

Keterangan: Berbeda nyata pada taraf $5 \%$ (huruf kecil yang berbeda ke arah kolom/lajur); Tidak berbeda nyata pada taraf $5 \%$ (huruf besar yang sama ke arah baris)

sawit pada ransum sampai level 30\% tidak menunjukkan pengaruh terhadap ketiga peubah yang diamati yaitu pertambahan bobot badan, konsumsi pakan, dan konversi pakan, namun perbedaan umur pada ayam Merawang memberikan pengaruh nyata terhadap konsumsi pakan, konversi pakan maupun pertambahan bobot badan pada penelitian ini. Interaksi antara pemberian bungkil sawit dengan umur ayam tidak memberikan pengaruh nyata terhadap pertambahan bobot badan, konsumsi pakan maupun konversi pakan, hal ini bisa dikatakan tidak adanya interaksi antara kedua faktor yang dilakukan dalam penelitian ini.

\section{DAFTAR PUSTAKA}

Andriyanto., A. S. Satyaningtijas., R. Yufiadri., R. Wulandari., V. M. Darwin, dan S. N. A. Siburian. 2015. Performan dan kecernaan pakan ayam broiler yang diberi hormon testosteron dengan dosis bertingkat. J. Ac-ta Veterinaria Indonesiana. 3 (1): 29-37.

Anggraini A. D., W. Widodo., I. D. Rahayu, dan A. Sutanto. 2019. Efektivitas Penambahan Tepung Temulawak dalam Ransum sebagai Upaya Peningkatan Produktivitas Ayam Kampung Super. Jurnal Sain Peternakan Indonesia Volume 14 Nomor 2 edisi April-Juni 2019 hal 222-227.

Astuti, N. 2012. Kinerja Ayam Kampung Dengan Ransum Berbasis Konsentrat
Briler. Jurnal Agrisains Vol 4(5): 51-58.

Badan Pusat Statistik. 2018. Statistik Kelapa Sawit Indonesia 2017.

Bidura, I. G. N. G. dan I. M. Suasta. 2006. Penampilan ayam kampong umur 0-8 minggu yang diberi tepung hipofisa kambing melalui ransum. Majalah Ilmiah Peternakan 9(1): 20- 24.

Dewanti, R. dan Sihombing, G. 2012. Analisis Pendapatan Usaha Peternakan Ayam Buras (Studi Kasus di Kecamatan Tegalombo, Kabupaten Pacitan). Buletin Peternakan Vol. 36(1): 48-56.

Ditjenbun. 2017. Satistik Perkebunan Indonesia 2015-2017 Kelapa Sawit. Kementerian Pertanian.

Fontana, E. A., W. D. Weaver., B. A. Watkins, and D. M. Denbow. 1992. Effect of early feed re-striction on growth, feed con-version and mortality in broiler chicken. Poult. Sci. 71(8):1296-1305.

Gomez and Gomez. 1984. Statistical procedures for agricultural research.

Hasnelly, Z., Rinaldi, dan Suwardih. 2006. Penangkaran dan perbibitan ayam Merawang di Bangka Belitung. Lokakarya Nasional. Inovasi Teknologi Dalam Mendukung Usaha Ternak Unggas Berdaya Saing. 75-81. Semarang, 4 Agustus 2006.

Iskandar, S., Resnawati, H. and Pasaribu, T. 2000. Growth and carcass responses of three lines of local chickens and its crossing to detary lysine and 
methionine in the Proc. of the 3rd International Seminar on Tropical Animal Production: Animal Production and Total Management of Local Resources. Faculty of Animal ScienceGadjah Mada University.

Iskandar, S., Desmayati. Z., S. Sastrodiharjo., T. Sartika., P. Setiadi, dan T. Susanti. 1998. Respon pertumbuhan ayam kampung dan silangan-pelung terhadap ransum berbeda kandungan protein. Jurnal Ilmu Ternak dan Veteriner 3(1): 8-14.

Majid, D. A. 2002. Performa Ayam Kampung dan Merawang (umur 5-12 minggu) Yang Diberi Bungkil Inti Sawit Dalam Ransumnya. Skripsi. Fakultas Peternakan. Institut Pertanian Bogor, Bogor.

Nataamijaya, A. G. 2010. Pengembangan Potensi Ayam Lokal untuk Menunjang Peningkatan Kesejahteraan Petani. Jurnal Litbang 29 (4): 131- 138.

Nuraini., Hidayat, Z. dan Yolanda, K. 2016. Identifikasi Karakteristik Genetik Eksternal Dan Ukuran Tubuh Ayam Merawang Di KP Petaling BPTP Kepulauan Bangka Belitung. Prosiding Seminar Nasional Kebangkitan Peternakan II 2016.

Nuraini., Hidayat, Z. dan Yolanda, K. 2018. Performa Bobot Badan Akhir, Bobot Karkas serta Persentase Karkas Ayam Merawang pada Keturunan dan
Jenis Kelamin yang Berbeda. Sains Peternakan Vol. 16 (2), September 2018: 69-73.

Pasaribu, T. 2018. Upaya meningkatkan kualitas bungkil inti sawit melalui teknologi fermentasi dan penambahan enzim untuk unggas. Wartazoa Vol. 28 No. 3 Th. 2018 Hlm.119-128.

Resnawati, H., Nataamijaya, A. G., Kusnadi, U., Hamid, H., Iskandar, S. dan Sugiyono. 2000. Optimalisasi teknologi budidaya ternak ayam lokal penghasil daging dan telur. Prosiding Seminar Nasional Teknologi Peternakan dan Veteriner. Bogor.

Sulandari, S., M. S. A. Zein., S. Priyanti., T. Sartika., M. Astuti., T. Widyastuti., E. Sujana., S. Darana., I. Setiawan, dan D. Garnida. 2007. Sumberdaya genetik ayam lokal Indonesia. Hal 45-104. Dalam Keanekaragaman Sumberdaya Hayati ayam Lokal Indonesia: Manfaat dan Potensi. Pusat Penelitian Biologi LIPI. Bogor.

Suryana, Y. M. 2014. Peningkatan kapasitas kebun percobaan mendukung pengembangan perbibitan ayam Kampung Unggul Badan Litbang (KUB) di Kalimantan Selatan. Laporan akhir kegiatan. Banjarbaru (Indonesia): BPTP Kalimantan Selatan.

Wahju, J. 2015. Ilmu Nutrisi Unggas. Cetakan Ke-6. Gadjah Mada University Press. Yogyakarta. 